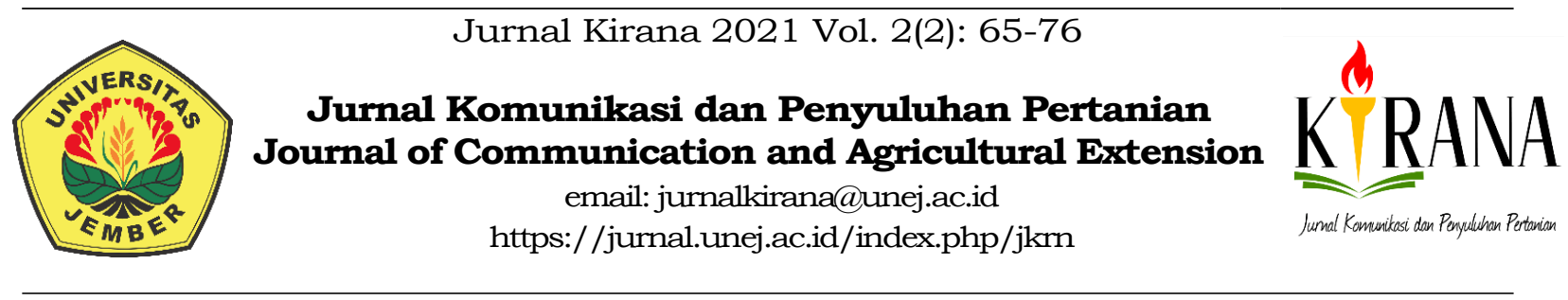

\title{
Keikutsertaan Program Asuransi Usaha Tani Padi (AUTP) di Pekon Tulung Agung Kecamatan Gadingrejo Kabupaten Pringsewu
}

\section{Participation of the Rice Farming Insurance Program (AUTP) in Tulung Agung Village Gadingrejo District Pringsewu Regency}

\section{Maria Ditha Ayu S. ${ }^{\otimes}$, Dame Trully Gultom ${ }^{1}$, Sumaryo Gitosaputro ${ }^{1}$}

${ }^{1}$ Program Studi Penyuluhan Pertanian Fakultas Pertanian Universitas Lampung

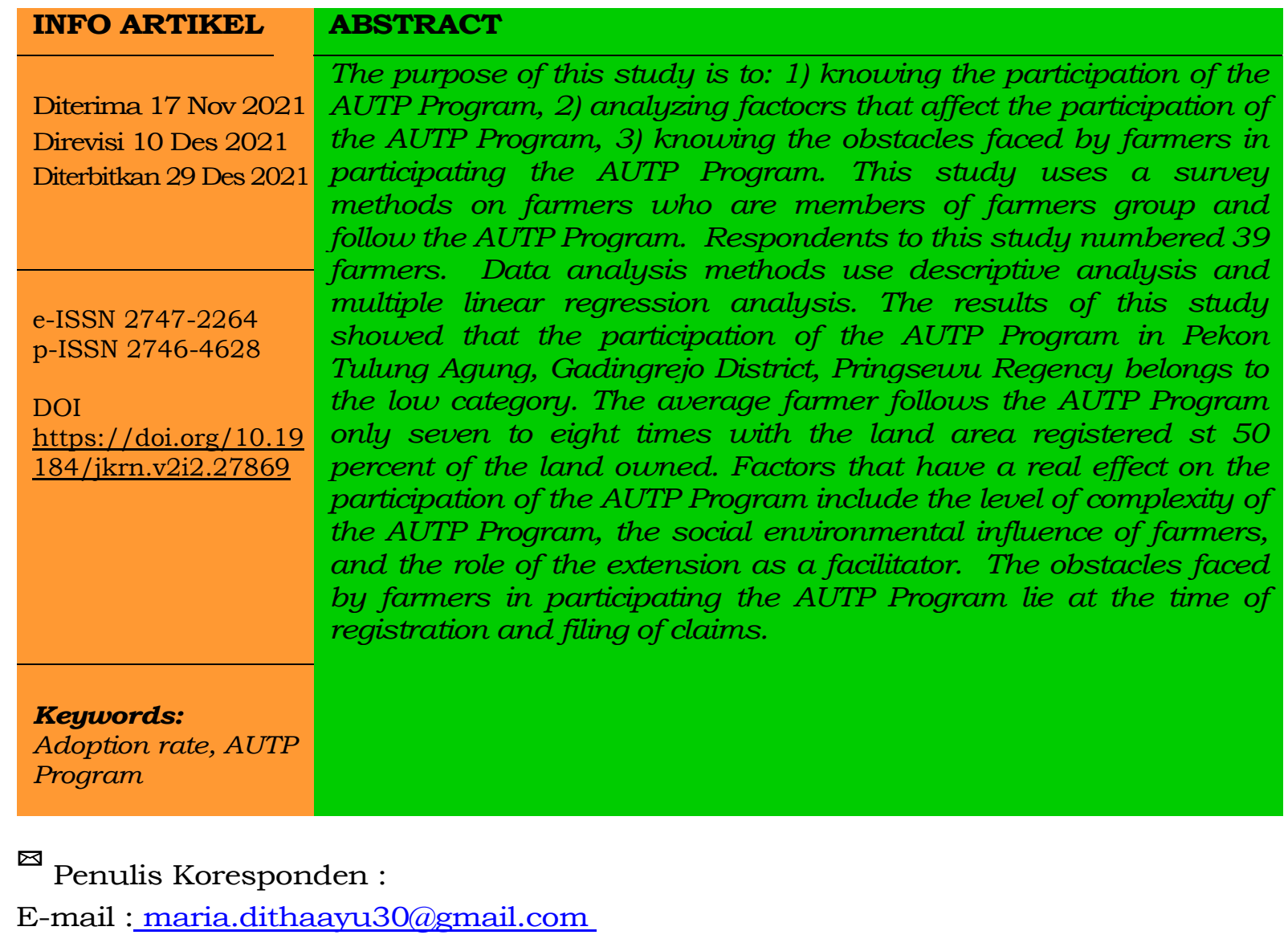




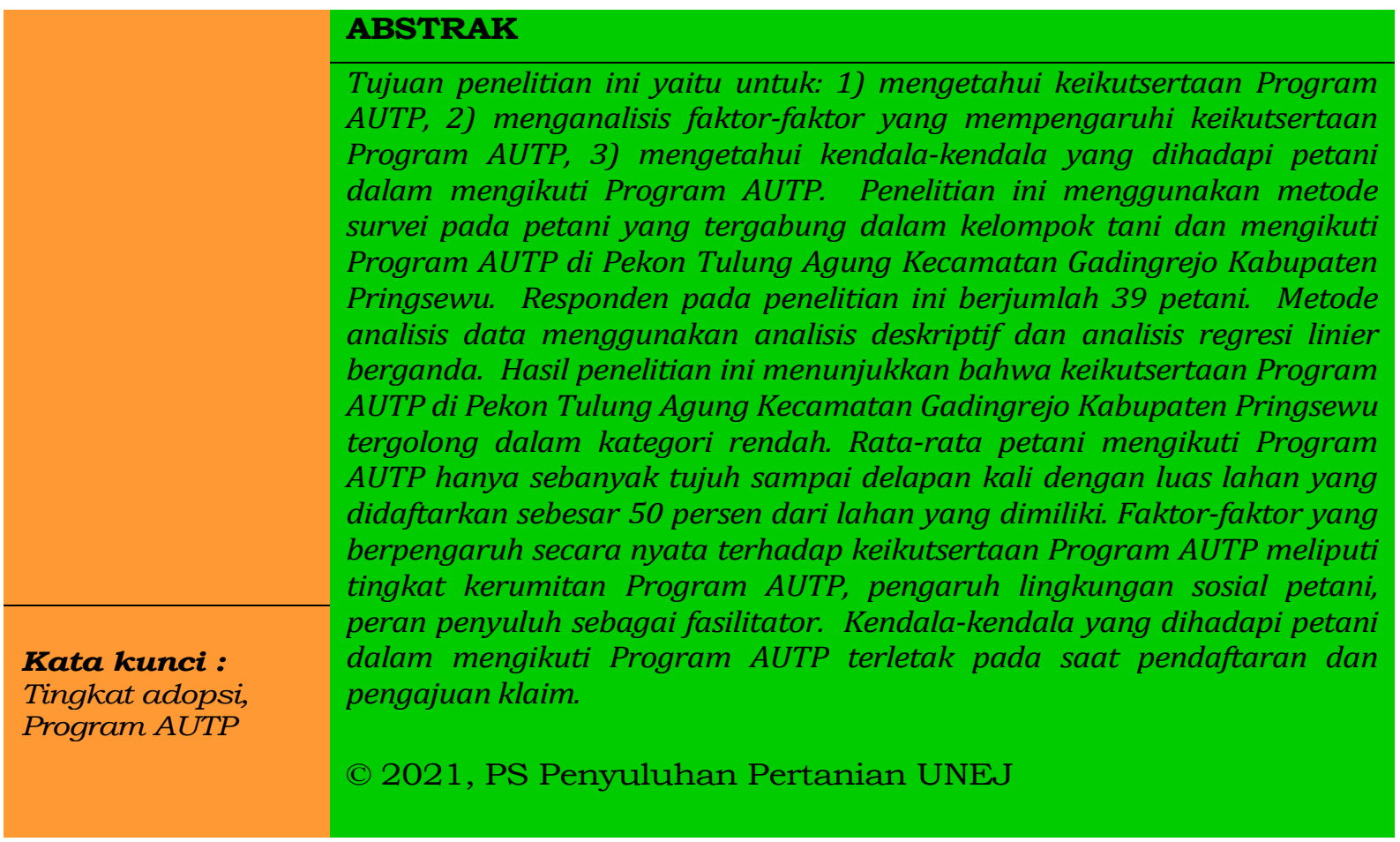

\section{PENDAHULUAN}

Sektor pertanian merupakan salah satu sektor yang sangat penting dalam perekonomian Indonesia karena berperan dalam menjalankan roda perekonomian dan memenuhi kebutuhan pangan di Indonesia. Program pemerintah dalam upaya untuk memenuhi kebutuhan pangan nasional khususnya kebutuhan beras terus menerus dilakukan melalui inovasi teknologi dan penerapan program perbaikan manajemen usaha tani mengingat beras sebagai bahan pangan pokok bagi rakyat Indonesia (Putri, et al., 2020).

Sektor pertanian merupakan salah satu sektor yang paling rawan terhadap dampak negatif perubahan iklim dan hama penyakit. Pemerintah membantu mengupayakan perlindungan usaha tani dalam bentuk asuransi pertanian untuk mengatasi kerugian petani, sebagaimana tercantum pada Undang- Undang Nomor 19 Tahun 2013 tentang Perlindungan dan Pemberdayaan Petani yang telah ditindaklanjuti dengan penerbitan Peraturan Menteri Pertanian No. 40 Tahun 2015 tentang Fasilitasi Asuransi Pertanian (Kementerian Pertanian, 2016).

Pemerintah membuat suatu inovasi yaitu program Asuransi Usaha tani Padi (AUTP) dimana dalam pelaksanaannya harus diadopsi oleh petani agar tujuan program dapat tercapai. Asuransi pertanian sangat penting bagi para petani untuk melindungi usaha taninya. Melalui Program Asuransi Usaha tani Padi (AUTP), jaminan dapat diberikan terhadap kerugian akibat kerusakan tanaman yang disebabkan oleh banjir, kekeringan, serta serangan hama dan penyakit tanaman (HPT) atau organisme pengganggu tanaman (OPT). Petani dapat mengajukan klaim (tuntutan) untuk memperoleh ganti rugi sehingga mampu melakukan atau melanjutkan kegiatan berusaha tani (Kementerian Pertanian, 2020). 
Program Asuransi Usaha Tani Padi (AUTP) telah diselenggarakan di beberapa provinsi di Indonesia, salah satunya adalah Provinsi Lampung. Berdasarkan data dari Dinas Ketahanan Pangan Tanaman Pangan dan Hortikultura Provinsi Lampung (2018), diketahui bahwa jumlah luas lahan yang didaftarkan menjadi peserta asuransi di Kabupaten Pringsewu paling tinggi yaitu 3.689,40 ha. Kabupaten Pringsewu merupakan satu dari 15 kabupaten atau kota yang berada di Provinsi Lampung dengan luas wilayah 62.500 ha. Salah satu kecamatan dengan produksi tertinggi di Kabupaten Pringsewu adalah Kecamatan Gadingrejo. Menurut Badan Pusat Statistik (2018), Gadingrejo memiliki luas panen sebesar 6.696 ha dengan produksi mencapai 36.440 ton. Kecamatan Gadingrejo memiliki 23 pekon, namun pada tahun 2018 hanya tujuh pekon. yang mengikuti program AUTP. Menurut data Dinas Pertanian Kabupaten Pringsewu (2018), Tulung Agung merupakan pekon yang paling tinggi mengikuti program tersebut. Luas lahan yang didaftarkan adalah sebesar 211,50 ha.

Program Asuransi Usaha Tani Padi (AUTP) merupakan program yang sudah direncanakan oleh pemerintah untuk membantu masyarakat petani dalam mengatasi kerugian akibat gagal panen, yang disebabkan oleh banjir, kekeringan, dan serangan hama dan penyakit tanaman (HPT) atau organisme penggangu tanaman (OPT), namun pada kenyataannya masih banyak petani yang belum mengikuti program AUTP (Kementerian Pertanian, 2020). Luas lahan panen di Kecamatan Gadingrejo adalah sebesar 6.696 ha dan luas lahan yang menjadi peserta AUTP di Kecamatan Gadingrejo adalah sebesar 604,305 ha. Hanya 10\% lahan petani yang ada di Kecamatan Gadingrejo yang didaftarkan dalam Program AUTP, hal itu masih terlalu kecil jika dibandingkan dengan luas lahan panen di Kecamatan Gadingrejo, sehingga perlu dilakukan penelitian apakah hal tersebut disebabkan karena program AUTP yang merupakan suatu inovasi belum bisa diterima oleh masyarakat petani. Berdasarkan masalah di atas, penelitian ini ingin melihat faktor-faktor yang mempengaruhi keikutsertaan program Asuransi Usaha Tani Padi (AUTP). Tujuan dari penelitian ini: (1) Mengetahui keikutsertaan Program AUTP, (2) Menganalisis faktor-faktor yang mempengaruhi keikutsertaan Program AUTP, (3) Mengetahui kendalakendala yang dihadapi petani dalam mengikuti Program AUTP.

\section{METODE PENELITIAN}

Metode yang digunakan dalam penelitian ini adalah penelitian survei dengan pendekatan deskriptif kuantitatif. Penelitian ini telah dilakukan pada April 2021. Pemilihan lokasi ini dilakukan dengan sengaja (pusposive) di Pekon Tulung Agung Kecamatan Gadingrejo Kabupaten Pringsewu dengan pertimbangan bahwa Pekon Tulung Agung merupakan pekon yang paling banyak mengikuti Program AUTP. Total sampel dalam penelitian ini adalah 39 responden dengan cara random sampling, sedangkan untuk mengetahui jumlah sampel pada masing-masing kelompok tani menggunakan alokasi proporsional. Penelitian ini menggunakan data primer dan data sekunder. Data primer yaitu data yang diperoleh dengan wawancara langsung. Data sekunder merupakan data yang diambil dari 
data-data yang telah tercatat atau memang sudah tersedia, seperti perpustakaan, laporan, buku, jurnal, data BPS Provinsi Lampung, BPS Kabupaten Pringsewu,, dinas pertanian Pringsewu, dan balai penyuluhan pertanian Kecamatan Gadingrejo. Teknik pengumpulan data dari penelitian ini menggunakan kuesioner dan dokumentasi. Tujuan pertama dan ketiga dijawab dengan analisis deskriptif, sedangkan tujuan kedua dijawab dengan analisis regresi linier berganda. Syarat uji yang harus dipenuhi meliputi sebelum melakukan analisis regresi yaitu uji asumsi klasik yang meliputi uji normalitas, heteroksedastisitas, dan uji multikolinearitas. Berikut persamaan regresi linier berganda:

$\mathrm{Y}=\mathrm{a}+\mathrm{b}_{1} \mathrm{X}_{1}+\mathrm{b}_{2} \mathrm{X}_{2}+\mathrm{b}_{3} \mathrm{X}_{3}+\mathrm{b}_{4} \mathrm{X}_{4}+\mathrm{b}_{5} \mathrm{X}_{5}+\mathrm{b}_{6} \mathrm{X}_{6}+\mathrm{b}_{7} \mathrm{X}_{7}+\mathrm{b}_{8} \mathrm{X}_{8}+\mathrm{e}$

Keterangan :

$\mathrm{Y} \quad$ : tingkat adopsi program AUTP

a : konstanta

$\mathrm{b}_{1}-\mathrm{b}_{8}$ : koefisien regresi

$\mathrm{X}_{1}$ : variabel umur responden

$\mathrm{X}_{2}$ : variabel tingkat pendidikan responden

$\mathrm{X}_{3}$ : variabel lama berusaha tani responden

$\mathrm{X}_{4}$ : variabel luas lahan responden

$\mathrm{X}_{5}$ : variabel sifat-sifat inovasi

$\mathrm{X}_{6}$ : variabel pengaruh lingkungan sosial responden

$\mathrm{X}_{7}$ : variabel peran penyuluh

$\mathrm{X}_{8}$ : variabel frekuensi keberhasilan klaim

e : eror

\section{HASIL DAN PEMBAHASAN}

\section{A. Karakteristik Responden}

\section{Umur Petani}

Umur dalam penelitian ini merupakan usia petani dari lahir hingga dilakukan penelitian ini. Sebaran responden pada penelitian ini berada pada rentang umur 15-64 tahun sebanyak 38 orang dengan presentase 97,43 persen. Umur responden pada penelitian ini termasuk dalam usia produktif dengan rata-rata umur responden berumur 46 tahun. Petani yang tergolong usia produkif lebih berpotensi dalam melakukan kegiatan usahatani, karena pada usia produktif kondisi fisik petani lebih kuat untuk menjalankan kegiatan usahatani secara optimal. Selain itu, usia yang produktif juga mempengaruhi petani dalam mengambil keputusan untuk mengikuti suatu program karena dengan petani.

\section{Tingkat Pendidikan Petani}

Tingkat pendidikan petani pada penelitian ini merupakan lamanya pendidikan secara formal yang ditempuh oleh petani. Responden pada penelitian ini memiliki pendidikan hingga tingkat Sekolah Menengah Atas (SMA) sebanyak 18 orang dengan presentase sebesar 48,15 persen. Ratarata tingkat pendidikan responden juga menunjukkan tingkat SMA. Hal ini menunjukkan bahwa responden pada penelitian ini telah menempuh pendidikan hingga tingkat Sekolah Menengah Atas (SMA). Semakin lama pendidikan yang ditempuh oleh responden, maka akan semakin mudah petani menerima inovasi-inovasi baru dibidang pertanian. 


\section{Lama Berusahatani Petani}

Lama berusahatani merupakan pengalaman petani dalam melakukan kegiatan berusahatani. Responden tergolong sedang dalam melakukan kegiatan usahataninya yaitu sebanyak 20 responden telah melakukan usahatani dalam rentang waktu 21-37 tahun dengan presentase 51,29 persen. Petani yang sudah masuk tergolong sedang dalam menjalankan kegiatan usahatani biasanya sudah memiliki pengalaman dalam melakukan usahataninya walaupun sebenarnya belum terlalu banyak, sehingga akan mampengaruhi keterampilan dan kebijakan petani dalam menghadapi permasalahan usahatani.

\section{Luas Lahan Petani}

Luas lahan petani merupakan luas areal persawahan yang digunakan petani dalam menjalankan usahatani padi. Responden memiliki luas lahan dengan rentang luas $0,5-1,0$ ha sebanyak 16 responden dengan presentase 41,02 persen. Luas lahan perkebunan kopi responden termasuk dalam kategori lahan sempit dengan rata-rata luas lahan 1,5 ha. Lahan persawahan mempengaruhi produksi padi yang dihasilkan. Jika lahan persawahan yang sempit, maka akan menghasilkan produksi padi yang semakin sedikit pula.

\section{B. Tingkat Kerumitan Program AUTP}

Kerumitan dalam Program AUTP merupakan suatu kesulitan yang dialami oleh petani dalam memengikuti Program AUTP. Kerumitan tersebut dapat menjadi kendala bagi petani dalam mengadopsi Program AUTP. Tingkat kerumitan Program AUTP meliputi tingkat kerumitan pada saat proses pendaftaran dan pengajuan klaim.

Tingkat kerumitan pada saat mendaftar menjadi peserta Program AUTP nilai modus yang muncul adalah 2 yang berarti proses pendaftaran tergolong cukup rumit, sedangkan tingkat kerumitan dalam proses pengajuan klaim asuransi dari PT Asuransi Jasindo nilai modus yang muncul adalah 3 yang berarti proses pengajuan klaim asuransi tergolong rumit. Berdasarkan data tersebut, maka dapat diketahui tingkat kerumitan terletak pada pendaftaran dan klaim asuransi.

Menurut penilaian petani, dalam mendaftar menjadi peserta Program AUTP cukup rumit karena pendaftaran dilakukan secara online melalui aplikasi SIAP (Sistem Informasi Asuransi Pertanian). Banyak petani yang tidak mengerti untuk mendaftar karena kurang mengerti teknologi/informasi maupun keterbatasan alat elektronik, namun pengurus kelompok tani, pengurus gabungan kelompok tani, dan penyuluh ikut membantu langsung saat proses pendaftaran. Proses pendaftaran Program AUTP tidak memerlukan berkas yang banyak. Petani hanya perlu menyiapkan KTP dan KK.

Sama halnya dengan proses pendaftaran, menurut penilaian petani, proses pengajuan klaim rumit. Banyaknya bukti yang harus dikumpulkan berupa foto-foto lahan yang terkena dampak kerusakan akibat serangan HPT/OPT, kekeringan, atau kebanjiran yang akurat. Foto-foto tersebut harus diambil dari berbagai sisi agar lahan yang terkena dampak kerusakan terlihat jelas. Dalam proses pengajuan klaim pun terdapat batasan waktu. 
Petani harus melaporkan dan menyerahkan bukti tidak boleh lebih dari seminggu setelah kejadian. Selain itu, dalam proses pengajuan klaim membutuhkan waktu yang cukup lama karena laporan harus dinilai terlebih dahulu oleh pihak asuransi dan dinas pertanian mengikuti syarat-syarat yang telah ditentukan oleh pihak terkait. Petani yang mengajukan klaim asuransi belum tentu laporannya diterima karena terkadang terdapat syarat yang kurang memenuhi seperti kerusakan lahan tidak mencapai 75 persen seperti yang tercantum.

\section{Pengaruh Lingkungan Sosial Petani}

Lingkungan sosial petani merupakan wilayah atau tempat dimana petani tinggal dan melakukan interaksi. Lingkungan sosial sangat mempengaruhi petani dalam mengambil keputusan untuk mengadopsi suatu program. Pengaruh lingkungan sosial petani di Pekon Tulung Agung Kecamatan Gadingrejo Kabupaten Pringsewu meliputi dukungan yang berasal dari keluarga, kelompok tani, dan penyuluh serta fasilitas yang diberikan oleh kelompok tani dan penyuluh untuk mengikuti Program AUTP.

Pengaruh lingkungan sosial petani yang berasal dari keluarga nilai modus yang muncul adalah 2 yang berarti keluarga hanya kadang-kadang memberikan dukungan kepada petani dalam mengikuti Program AUTP, sedangkan pengaruh lingkungan sosial petani yang berasal dari kelompok tani dan penyuluh nilai modus yang muncul adalah 3 yang berarti kelompok tani dan penyuluh selalu mendukung petani dalam mengikuti Program AUTP. Berdasarkan data tersebut, maka diketahui petani kurang mendapat dukungan dari kelurga, namun petani mendapat dukungan dari kelompok tani dan penyuluh.

Dukungan keluarga pada penelitian ini merupakan upaya yang dilakukan keluarga untuk membantu petani dalam mengambil keputusan untuk mengikuti Program AUTP. Program AUTP dibuat oleh pemerintah untuk membantu petani jika terjadi gagal panen akibat kekeringan, kebanjiran, ataupun serangan HPT/OPT. Pada penelitian ini, keluarga mendukung petani walaupun hanya kadang-kadang. Dukungan yang diberikan yaitu berupa dukungan moril dan mengingatkan petani untuk mendaftar menjadi peserta Program AUTP. Selain itu, keluarga juga mengingatkan untuk mengecek lahan agar jika terjadi kerusakan akibat kekeringan, kebanjiran, atau serangan HPT/OPT dapat segera mengajukan klaim.

Selain dukungan keluarga, dukungan kelompok tani juga mempengaruhi petani dalam mengikuti Program AUTP. Kelompok tani di Pekon Tulung Agung sangat mendukung petani untuk mengikuti Program AUTP. Pertemuan kelompok tani diadakan setiap satu bulan sekali. Setiap pertemuan, pengurus kelompok tani memberikan sosialisasi mengenai Program AUTP dan selalu mengajak petani untuk mendaftar menjadi peserta Program AUTP karena program tersebut dapat memberikan jaminan kepada petani jika terjadi gagal panen akibat kekeringan, kebanjiran, atau serangan HPT/OPT. Pengurus kelompok tani juga membantu petani dalam proses pendaftaran dan pengajuan klaim. Tidak semua petani mempunyai telepon genggam atau HP dan mengerti teknologi, untuk itu pengurus kelompok tani 
membantu langsung dalam proses pendaftaran karena pendaftaran Program AUTP dilakukan secara online melalui aplikasi, petani hanya perlu menyiapkan KTP dan KK. Pengurus kelompok tani juga membantu selama proses pengajuan klaim. Jika ada petani yang melaporkan kalau lahannya rusak akibat kekeringan, kebanjiran, atau serangan HPT/OPT, pengurus kelompok tani dibantu pengurus gabungan kelompok tani langsung turun ke lahan yang rusak tersebut dan membantu untuk mengumpulkan bukti yang nantinya akan diserahkan kepada penyuluh.

Penyuluh juga ikut mendukung petani untuk mengikuti Program AUTP. Pertemuan penyuluh dengan petani yang membahas mengenai Program AUTP diadakan dua kali dalam satu musim tanam. Pada awal musim tanam, penyuluh memberikan sosialisasi mengenai Program AUTP bahwa program tersebut akan memberikan jaminan kepada petani jika terjadi gagal panen dan penyuluh mengajak petani untuk mengikuti program tersebut. Dukungan yang diberikan penyuluh adalah membantu petani dalam proses pendaftaran dan penagjuan klaim. Selain itu, penyuluh juga selalu memberikan motivasi kepada petani untuk terus ikut dalam program tersebut. Motivasi yang berikan penyuluh yaitu berupa kata-kata penyemangat walaupun petani sudah mengajukan klaim namun belum di acc oleh pihak asuransi dan dinas pertanian, petani diharapkan tetap mengikuti Program AUTP karena akan memberikan keuntungan.

\section{Peran Penyuluh sebagai Fasilitator}

Peran penyuluh sebagai fasilitator merupakan suatu tindakan yang diberikan oleh penyuluh untuk membantu petani dalam mengikuti Program AUTP. Penyuluh memiliki peran yang sangat tinggi untuk mempengaruhi petani dalam mengambil suatu keputusan. Peran penyuluh sebagai fasilitator di Pekon Tulung Agung Kecamatan Gadingrejo Kabupaten Pringsewr meliputi fasilitas (bantuan/pandampingan) yang diberikan penyuluh kepada petani pada saat proses pendaftaran menjadi peserta Program AUTP dan mendapatkan klaim asuransi.

Peran penyuluh sebagai fasilitator pada saat proses pendaftaran menjadi peserta Program AUTP dan mendapatkan klaim asuransi nilai yang muncul adalah 2 yang berarti penyuluh hanya kadang-kadang memfasilitasi petani untuk mengikuti Program AUTP. Berdasarkan data tersebut, maka dapat diketahui bahwa penyuluh kurang memberikan fasilitas kepada petani dalam mengikuti Program AUTP.

Menurut penilaian petani di Pekon Tulung Agung, penyuluh tetap memfasilitasi petani dalam mengikuti Program AUTP. Pada saat proses pendaftaran, penyuluh meminjamkan laptop/hp untuk melakukan pendaftaran karena ada petani yang tidak memiliki telepon genggam dan kurang mengerti teknologi/informasi sehingga penyuluh membantu dan mendampingi secara langsung selama proses pendaftaran, namun terkadang penyuluh memiliki kesibukan lain yang menyebabkan penyuluh tidak bisa datang untuk memfasilitasi petani, sehingga proses pendaftaran dibantu oleh pengurus kelompok tani. Begitupun pada saat proses pengajuan klaim, jika petani ada yang melaporkan kalau lahannya mengalami kerusakan, penyuluh langsung datang untuk melihat langsung lahan tersebut dan 
membantu mengambilkan foto untuk dijadikan sebagai bukti, namun terkadang penyuluh berhalangan hadir dikarenakan ada kepentingan lain, sehingga hanya didampingi oleh pengurus kelompok tani dan pihak asuransi.

\section{E. Frekuensi Keberhasilan Klaim}

Keberhasilan klaim merupakan capaian klaim yang berhasil didapatkan petani dalam megikuti Program AUTP. Keberhasilan klaim dilihat dari berapa kali petani mendapatkan uang ganti rugi dari Program AUTP. Frekuensi keberhasilan klaim di Pekon Tulung Agung diukur dengan memberikan pertanyaan terkait berapa kali petani mendapatkan klaim asuransi.

Berdasarkan hasil penelitian menunjukkan bahwa, sebanyak 21 orang petani belum pernah mendapatkan klaim asuransi dengan presentase sebesar 53,84 persen. Sedangkan, 18 orang petani lainnya hanya pernah mendapatkan klaim asuransi sebanyak satu kali dengan presentase sebesar 46,16 persen. Hal ini menunjukkan bahwa banyak petani yang tidak mendapatkan uang ganti rugi (klaim asuransi) walaupun sudah mengajukan klaim. Petani bisa mendapatkan uang ganti rugi jika petani sudah memenuhi syarat-syarat yang sudah ditentukan. Ada beberapa penyebab yang mengakibatkan pengajuan klaim petani tidak diterima oleh pihak asuransi dan dinas pertanian, yaitu luas lahan kerusakan tidak mencapai 75 persen, waktu pengajuan klaim terlambat, dan bukti-bukti yang dikumpulkan tidak valid. Namun, walaupun sebagian besar petani sudah mengajukan klaim dan tidak diterima oleh pihak asuransi dan dinas pertanian, mereka tetap mengikuti Program AUTP karena untuk berjaga-jaga jika suatu saat terjadi gagal panen akibat kekeingan, kebanjiran, ataupun serangan HPT/OPT mereka memiliki jaminan ganti rugi.

\section{F. Keikutsertaan Program AUTP}

Keikutsertaan Program AUTP pada penelitian ini diukur dengan memberikan pernyataan kepada petani. Keikutsertaan Program AUTP di Desa Tulung Agung Kecamatan Gadingrejo Kabupaten Pringsewu meliputi persentase musim tanam yang diikutsertakan petani dalam Program AUTP dan persentase lahan yang di asuransikan. Keikutsertaan Program AUTP pada penelitian ini dapat dilihat pada tabel berikut.

Tabel 1. Keikutsertaan Program AUTP

\begin{tabular}{lccc}
\hline Kategori & $\begin{array}{c}\text { Kelas } \\
\text { interval (\%) }\end{array}$ & $\begin{array}{c}\text { Jumlah } \\
\text { (orang) }\end{array}$ & $\begin{array}{c}\text { Persentase } \\
\text { (\%) }\end{array}$ \\
\hline Rendah & $57,6-66,16$ & 15 & 38,47 \\
Sedang & $66,17-74,73$ & 11 & 28,20 \\
Tinggi & $74,74-83,3$ & 13 & 33,33 \\
\hline Jumlah & & 39 & 100,00 \\
\hline
\end{tabular}

Tabel 1 menunjukkan bahwa keikutsertaan Program AUTP di Pekon Tulung Agung Kecamatan Gadingrejo Kabupaten Pringsewu berada pada kategori rendah dengan kelas interval 57,6-66,16 persen, jumlah petani sebamyak 15 orang, dan presentase sebesar 38,47 persen. Program AUTP di Pekon Tulung Agung telah dilaksanakan sejak tahun 2017, sehingga jika dihitung dari tahun 2017 sampai tahun 2021 terdapat sembilan kali musim 
tanam. Pada penelitian ini, rata-rata dari petani mengikuti Program AUTP sebesar 83,98 persen atau sebanyak tujuh sampai delapan kali pada musim tanam satu dan musim tanam dua. Banyak petani yang mengikuti Program AUTP kurang dari sembilan kali dikarenakan tidak memiliki uang untuk membayar premi, tidak memiliki keinginan untuk mendaftar, atau bahkan tidak merasakan keuntungan dari Program AUTP.

Petani di Pekon Tulung Agung jarang mengajukan klaim asuransi, paling banyak mereka hanya pernah mengajukan klaim sebanyak tiga kali dan dari tiga kali pengajuan tersebut hanya satu kali di acc oleh pihak asuransi, selebihnya petani hanya pernah mengajukan klaim sebanyak satu kali. Walaupun petani jarang mengajukan klaim, petani tetap mengikuti Program AUTP setiap tahunnya karena petani ingin melindungi usahataninya dari kebanjiran, kekeringan, atau serangan OPT / HPT.

Tidak semua lahan yang dimiliki petani diikutsertakan dalam Program AUTP karena ada sebagian lahan yang tidak ditanami tanaman padi melainkan ditanami tanaman palawija dan terdapat kuota untuk masing-masing petani dalam mengikuti Program AUTP sehingga petani tidak bisa mendaftarkan seluruh lahan yang dimiliki dalam Program AUTP. Luas lahan petani di Pekon Tulung Agung termasuk dalam kategori sempit yaitu paling luas sebesar 2 ha dan paling sempit sebesar 0,5 ha. Pada penelitian ini, rata-rata petani mengasuransikan lahannya dalam Program AUTP sebanyak 53,61 persen dari lahan yang dimiliki.

Jika dilihat dari tahapan-tahapan adopsi, responden pada penelitian ini sudah mengadopsi Program AUTP sampai tahap adopsi. Beberapa petani mulai mengikuti Program AUTP dari tahun 2017 musim tanam satu, namun ada sebagian petani yang mengikuti Program AUTP pada tahun 2018, 2019, 2020, ataupun 2021. Setiap petani tidak sama dalam mengadopsi Program AUTP. Ada petani yang langsung mengikuti Program AUTP saat program tersebut disosialisasikan, namun ada pula petani yang tidak langsung mengikuti program tersebut dikarenakan ingin melihat terlebih dahulu dari pengalaman petani lainnya yang sudah mengikuti program tersebut, apakah Program AUTP menguntungkan atau tidak.

\section{G. Faktor - Faktor yang Mempengaruhi Keikutseetaan Program AUTP}

Faktor-faktor yang mempengaruhi keikutsertaan Program AUTP di Pekon Tulung Agung Kecamatan Gadingrejo Kabupaten Pringsewu diuji melalui analisis regresi linear berganda dengan alat bantu SPSS 26.0. Variabel bebas (X) dalam penelitian ini yaitu umur $\left(\mathrm{X}_{1}\right)$, tingkat pendidikan $\left(\mathrm{X}_{2}\right)$, lama berusahatani $\left(\mathrm{X}_{3}\right)$, luas lahan $\left(\mathrm{X}_{4}\right)$, tingkat kerumitan Program AUTP $\left(\mathrm{X}_{5}\right)$, pengaruh lingkungan sosial petani $\left(\mathrm{X}_{6}\right)$, peran penyuluh sebagai fasilitator $\left(X_{7}\right)$, dan frekuensi keberhasilan klaim $\left(\mathrm{X}_{8}\right)$, sedangkan variabel terikat $(\mathrm{Y})$ dalam penelitian ini yaitu keikutsertaan Program AUTP. Berikut hasil analisis regresi linier berganda yang diperoleh untuk mengetahui faktor-faktor yang mempengaruhi tingkat adopsi Program AUTP. 
Analisis regresi linier berganda tersebut kemudian dirumuskan dalam bentuk persamaan regresi linier berganda sebagai berikut:

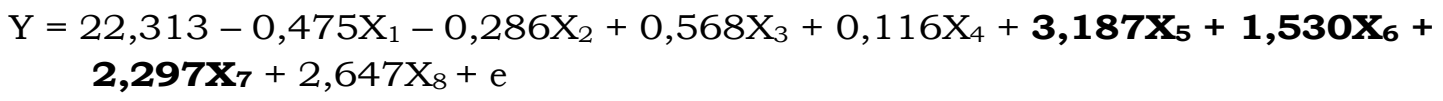

Berdasarkan persamaan tersebut dapat diartikan bahwa:

a. Jika terjadi peningkatan ketidakrumitan Program AUTP sebesar satu persen, maka tingkat adopsi Program AUTP akan cenderung mengalami peningkatan sebesar 3,187 persen.

b. Jika terjadi peningkatan pengaruh lingkungan sosial petani sebesar satu persen, maka tingkat adopsi Program AUTP akan cenderung mengalami peningkatan sebesar 1,530 persen.

c. Jika terjadi peningkatan peran penyuluh sebagai fasilitator sebesar satu persen, maka tingkat adopsi Program AUTP akan cenderung mengalami peningkatan sebesar 2,297 persen.

Tabel 4. Hasil Analisis Regresi Linier Berganda Coefficientsa

\begin{tabular}{|c|c|c|c|c|c|c|}
\hline \multirow{2}{*}{\multicolumn{2}{|c|}{ Model }} & \multicolumn{2}{|c|}{$\begin{array}{l}\text { Unstandardized } \\
\text { Coefficients }\end{array}$} & \multirow{2}{*}{$\begin{array}{c}\text { Standardized } \\
\text { Coefficients } \\
\text { Beta }\end{array}$} & \multirow[b]{2}{*}{$\mathrm{t}$} & \multirow[b]{2}{*}{ Sig. } \\
\hline & & B & $\begin{array}{l}\text { Std. } \\
\text { Error }\end{array}$ & & & \\
\hline \multirow[t]{12}{*}{1} & (Constant) & 16,437 & 45,405 & & 0,362 & 0,720 \\
\hline & Umur petani & $-1,180$ & 0,916 & $-0,549$ & $-1,289$ & 0,207 \\
\hline & $\begin{array}{l}\text { Tingkat pendidikan } \\
\text { petani }\end{array}$ & 0,503 & 1,111 & 0,064 & 0,452 & 0,654 \\
\hline & $\begin{array}{l}\text { Lama berusahatani } \\
\text { petani }\end{array}$ & 1,545 & 0,899 & 0,725 & 1,719 & 0,096 \\
\hline & Luas lahan petani & 0,293 & 0,153 & 0,290 & 1,917 & 0,065 \\
\hline & $\begin{array}{l}\text { Tingkat kerumitan } \\
\text { Program AUTP }\end{array}$ & 6,403 & 2,988 & 0,325 & 2,143 & 0,040 \\
\hline & $\begin{array}{l}\text { Pengaruh } \\
\text { lingkungan sosial } \\
\text { petani }\end{array}$ & 3,803 & 1,824 & 0,288 & 2,085 & 0,046 \\
\hline & $\begin{array}{l}\text { Peran penyuluh } \\
\text { sebagai fasilitator }\end{array}$ & 5,783 & 2,852 & 0,324 & 2,048 & 0,049 \\
\hline & $\begin{array}{l}\text { Frekuensi } \\
\text { keberhasilan klaim }\end{array}$ & 3,511 & 5,633 & 0,088 & 0,623 & 0,538 \\
\hline & F hitung & 3,090 & & & & 0,012 \\
\hline & $\mathrm{R}$ square & 0,452 & & & & \\
\hline & Adjusted R-Square & 0,306 & & & & \\
\hline
\end{tabular}

a. Dependent variabel: Tingkat adopsi

Sumber: Data Primer Diolah, 2021

Berdasarkan hasil analisis regresi dapat diketahui bahwa nilai $F_{\text {hitung }}$ sebesar 3,934 dengan nilai signifikan sebesar 0,003, sedangkan nilai $F_{\text {tabel }}$ pada penelitian ini sebesar 2,250, sehingga didapatkan nilai $F_{\text {hitung }}>F_{\text {tabel }}(3,934>2,250)$. Menurut Ghazali (2011), jika nilai sig. < 0,05, maka variabel independen (X) secara simultan berpengaruh terhadap variabel dependen $(\mathrm{Y})$, sedangkan jika nilai $F_{\text {hitung }}>F_{\text {tabel }}$, maka 
variabel independen (X) secara simultan berpengaruh terhadap variabel dependen (Y). Berdasarkan pernyataan tersebut maka diketahui bahwa variabel umur $\left(\mathrm{X}_{1}\right)$, tingkat pendidikan formal $\left(\mathrm{X}_{2}\right)$, lama berusahatani $\left(\mathrm{X}_{3}\right)$, luas lahan $\left(\mathrm{X}_{4}\right)$, tingkat kerumitan Program AUTP $\left(\mathrm{X}_{5}\right)$, pengaruh lingkungan sosial petani $\left(\mathrm{X}_{6}\right)$, peran penyuluh sebagai fasilitator $\left(\mathrm{X}_{7}\right)$, dan frekuensi keberhasilan klaim $\left(\mathrm{X}_{8}\right)$ secara simultan berpengaruh terhadap keikutsertaan Program AUTP di Pekon Tulung Agung Kecamatan Gadingrejo Kabupaten Pringsewu.

Nilai $R$ Square pada penelitian ini sebesar 0,512. Hal ini mengartikan besarnya pengaruh variabel $\mathrm{X}$ yang meliputi umur $\left(\mathrm{X}_{1}\right)$, tingkat pendidikan formal $\left(\mathrm{X}_{2}\right)$, lama berusahatani $\left(\mathrm{X}_{3}\right)$, luas lahan $\left(\mathrm{X}_{4}\right)$, tingkat kerumitan Program AUTP $\left(\mathrm{X}_{5}\right)$, pengaruh lingkungan sosial petani $\left(\mathrm{X}_{6}\right)$, peran penyuluh sebagai fasilitator $\left(X_{7}\right)$, dan frekuensi keberhasilan klaim $\left(X_{8}\right)$ terhadap keikutsertaan Program AUTP sebesar 51,2 persen, sedangkan sisanya 48,8 persen dipengaruhi oleh variabel lain yang tidak diteliti.

Uji t dilakukan untuk mengetahui pengaruh dari masing-masing variabel independen terhadap variabel dependen. $\mathrm{Uji} t$ dilakukan dengan melihat perbandingan nilai $t_{\text {hitung }}$ dan $t_{\text {tabel. }}$ Nilai $t_{\text {tabel }}$ pada penelitian ini adala sebesar 2,039. Jika $t_{\text {hitung }}>t_{\text {tabel }}$ maka $\mathrm{H}_{1}$ diterima. nilai thitung yang lebih kecil dari $t_{\text {tabel }}$ adalah variabel umur $\left(\mathrm{X}_{1}\right)$, tingkat pendidikan $\left(\mathrm{X}_{2}\right)$, lama berusahatani $\left(\mathrm{X}_{3}\right)$, luas lahan $\left(\mathrm{X}_{4}\right)$, dan frekuensi keberhasilan klaim $\left(\mathrm{X}_{8}\right)$. Hal ini menunjukkan bahwa $\mathrm{H}_{1}$ ditolak, artinya umur, tingkat pendidikan, lama berusahatani, luas lahan, dan frekuensi keberhasilan klaim secara sendiri-sendiri tidak berpengaruh secara nyata terhadap keikutsertaan Program AUTP. Nilai thitung yang lebih besar dari tabel yaitu tingkat kerumitan Program AUTP $\left(\mathrm{X}_{5}\right)$, pengaruh lingkungan sosial petani $\left(\mathrm{X}_{6}\right)$, dan peran penyuluh sebagai fasilitator $\left(\mathrm{X}_{7}\right)$. Hal ini menunjukkan bahwa $\mathrm{H}_{1}$ diterima, artinya tingkat kerumitan Program AUTP, pengaruh lingkungan sosial petani, dan peran penyuluh sebagai fasilitator secara parsial berpengaruh secara nyata terhadap keikutsertaan Program AUTP di Pekon Tulung Agung Kecamatan Gadingrejo Kabupaten Pringsewu.

\section{KESIMPULAN}

Keikutsertaan Program Asuransi Usaha Tani Padi (AUTP) di Pekon Tulung Agung Kecamatan Gadingrejo Kabupaten Pringsewu berada pada kategori rendah. Rata-rata petani mengikuti Program AUTP hanya sebanyak tujuh sampai delapan kali dengan luas lahan yang didaftarkan sebesar 50 persen dari luas lahan yang dimiliki. Tingkat kerumitan Program AUTP, pengaruh lingkungan sosial petani, dan peran penyuluh sebagai fasilitator berpengaruh terhadap keikutsertaan Program AUTP, sedangkan umur, tingkat pendidikan, lama berusahatani, luas lahan, dan frekuensi keberhasilan klaim tidak berpengaruh terhadap keikutsertaan Program AUTP.

Kendala yang dialami oleh petani di Pekon Tulung Agung Kecamatan Gadingrejo Kabupaten Pringsewu selama mengikuti Program AUTP adalah saat proses pendaftaran dan proses pengajuan klaim karena pendaftaran Program 
AUTP dilakukan secara online melalui aplikasi dan pengajuan klaim harus mengumpulkan bukti berupa foto lahan kerusakan yang diambil dari berbagai sisi dan proses pengajuan cukup lama. Selain itu, terdapat kuota luas lahan yang dapat didaftarkan dalam Program AUTP, sehingga petani tidak bisa mendaftarkan keseluruhan lahan yang dimiliki dalam Program AUTP.

\section{DAFTAR PUSTAKA}

Badan Pusat Statistik. (2018). Pringsewu dalam Angka. Lampung: BPS Kabupaten Pringsewu, Lampung, Indonesia.

Dinas Ketahanan Pangan Tanaman Pangan dan Hortikultura Provinsi Lampung. (2018). Data Auransi Usahatani Padi (AUTP) Kabupaten/Kota Provinsi Lampung Tahun 2018. Lampung: Dinas Pertanian Provinsi Lampung.

Dinas Pertanian Kabupaten Pringsewu. (2018). Daftar Pekon/Pekon Peserta AUTP di Kecamatan Gadingrejo Tahun 2018. Pringsewu: Dinas Pertanian Kabupaten Pringsewu.

Ghazali. (2011). Aplikasi Analisis Multivariate dengan Program SPSS. Semarang: Universitas Diponegoro.

Kementerian Pertanian. (2016). Pedoman Bantuan Premi Asuransi Usahatani Padi. Direktorat Jenderal Prasarana dan Sarana Pertanian. Jakarta: Kementerian Pertanian.

Pedoman Bantuan Premi Asuransi Usahatani Padi. Direktorat Jenderal Prasarana dan Sarana Pertanian. (2020). Jakarta: Kementerian Pertanian.

Putri, S. ., Gitosaputro, S., \& A.S., Y. (2020). Motivasi Petani Mengikuti Program Asuransi Usaha Tani Padi di Kabupaten Lampung Tengah. Journal of Extension and Development, 2(1), 45-53. 